\title{
Acquisition of the Alveo-Palatal Fricative /3/ in L2 English and Jamaican Creole: $A$ Comparative Study
}

\author{
Ahmed Mousa \\ King Abdulaziz University, Jeddah, Saudi Arabia \\ Email: aimousa2004@yahoo.com \\ Received 9 April 2015; accepted 10 June 2015; published 16 June 2015 \\ Copyright (C) 2015 by author and Scientific Research Publishing Inc. \\ This work is licensed under the Creative Commons Attribution International License (CC BY). \\ http://creativecommons.org/licenses/by/4.0/

(c) (i) Open Access

\begin{abstract}
This study investigates the claim that the strategies employed by second/foreign language learners are the same as those used by speakers of Creole languages. The speech of two speakers of the well-known Broad Jamaican Creole is checked against the performance of Saudi learners of English, focusing on the production of the voiced alveo-palatal fricative $/ 3 /$. The findings suggest that the speakers in the two groups produce the voiced affricate/dz/ instead, suggesting perhaps that the above claim is valid. This study provides external evidence to the validity of such theories as sound substitution, markedness, and historical sound change which are said to shape early language acquisition, including child language.
\end{abstract}

\section{Keywords}

\section{Alveo-Palatal Fricative, Broad Jamaican Creole, Saudi Learners of English, Creole, Language Acquisition}

\section{Introduction}

In this study an attempt is made to see to what extent the claim that the strategies employed by second/foreign language learners are similar to those used by speakers of Creole languages. Though it is important in the linguistic behaviour, the domain of phonology in second/foreign language learning and pidgin and creole languages has received little attention compared to the other aspects of language. Research has shown that child language, second/foreign language learning and pidgin and creole languages are more or less related in terms of processing. Many phenomena in these fields have been shown to be similar (Cook, 1993; Bickerton, 1995, Washabaugh, 1977; Schumann, 1978; Holm, 2000). Moreover, research on processes of pidginization and creo- 
lization has led to important advances in a number of areas of applied linguistics and theoretical linguistics (c.f. Holm, 2000). In this study, the strategies of language learning observed in the speech of Arab L2 learners of English, especially in the acquisition of the voiced alveo-palatal fricative $/ 3 /$, are compared to the process of de/creolization of two speakers of Board Jamaican Creole (Bailey, 1966). The similarities between the two Creole speakers and Arab learners will be highlighted drawing on the assumption that "the dynamics by which pidgins and creoles come into being and the development of the L2 learner's interlanguage might be governed by the same factors" Cook (1993: p. 69). That is, in both situations the behaviour of those concerned is constrained by the principles of Universal Grammar, a genetically determined pre-disposition for language. Furthermore, we assume that second language learning, de/creolization and historical change are significantly linked, in such a way that accounting for the behaviour of the first two is never precise in the absence of historical facts.

\section{Literature Review}

As an interesting and promising domain of linguistic research, the comparison of non-native language acquisition with pidginization/creolization has attracted a significant number of linguists. This is so because researchers have come to realize that, in order to understand the behaviour of early and late L1 acquisition as well as second/foreign language learning, appreciation of the processes involved in pidginization/depidginization, creolization/decreolization is a key issue McLaughlin (1987). For instance, Baxter et al. (1997), in their investigation of the Brazilian spoken dialect of Helvecia, observed a series of parallels with structures in early stages of L1 Portuguese acquisition.

In a comparison between the decreolization of the Guyanese Creole negation system and the acquisition of English negation by Spanish speakers, Schumann (1978) found that the overall movement along the linguistic continuum in the two operations involved a rule change from a basilect/basilange preverbal negation to the target English post-copula auxiliary negation. Furthermore, it was observed that the above rule change in the situations was accomplished by identical linguistic processes. That is, the replacement of surface forms and the restructuring of underlying units. Likewise, in the depidginization of Hawaiian Pidgin English, as reported by Bickerton and Odo (1976), a continuum of development occurs which is similar to that produced in decreolization and second language acquisition.

Patrick-Andre (2006), in a recent study, has come to the conclusion that many of the features found in Haitian French-lexifier creoles do occur in L2 French and other interlanguages, as a result of L1 transfer and other acquisition processes. The investigation includes word-order within the noun phrase, pronominal clitics, the absence of copula, grammatical gender, and verb movement. The major claim of the model of Creole genesis advocated in the study which he calls gradualist/second language acquisition, is that Creole genesis does not involve any specific mental processes or strategies other than those attested in ordinary second language acquisition. In Lefebvre et al. (2003), a number of second language researchers and Creolists engage in dialogues which focus on the processes characterizing various stages of L2 acquisition and Creole genesis, such as relexification and transfer from L1 and their role in the initial state. The dialogues also cover morphological, phonological, semantic and syntactic properties of interlanguage grammar and Creole grammars. Their findings lend support to the view that the same processes are found to shape the initial stages of the two situations.

\section{Current Study}

This study aims at investigating to what extent the linguistic processes exhibited in the creolization/decreolization parallel those manifested by L2 learners of English. Furthermore, it is assumed that foreign/second language learning, de/creolization and historical change are significantly linked, in such a way that accounting for these two learning situations is never precise without historical explanations. Thus, another aim of this study is to see to what extent the behaviour of the speakers of the Board Jamaican Creole and L2 learners exhibit facts of historical change. The study will focus on the acquisition of the voiced alveo-palatal fricative /3/. The sound has been chosen due to the following reason. The author who has been teaching English for many years has noticed that his Arab learners, like the two Jamaican in formants with whom he spent two years, consistently produce the above fricative as the voiced affricate /dz/. This observation has led to the investigation whose objectives have been outlined above. The study draws on the concept of transfer (Broselow, 1983) and markedness (Eckman, 1977) as two important factors that play major roles in shaping the learners’ phonological acquisition. But 
prior to embarking on our investigation, introducing the Jamaican speakers and the Arab learners is necessary.

\section{Methodology}

\subsection{Subjects}

The subjects of this study fall into two categories: Jamaican Creole speakers and Arab Learners of L2 English. The first category consists of two speakers of what is called the Broad Jamaican Creole (Bailey, 1966) of nearly the same age. The first one Mr. Mike (the barber henceforth), is from Hanover in the west of Jamaica. He migrated to Britain when he was 18 years old. Today he is 61 years old. He is a barber in Moss Side, Manchester, England. Most of his customers are West Indies, old and young. He uses the same language (Broad Jamaican Creole) at work, home and everywhere. He is always in touch with the West Indies people. He has little education. He left school before the age of 18 and his reading and writing are not perfect. The second informant, Mr. Norman (the driver henceforth), is from St. Mary in the north of Jamaica. He migrated to Britain when he was 17. Today he is 59 years old. He worked in two factories in Manchester, as a dry cleaner, and as a carpet fitter before he became a taxi-driver, which is his present job. He also studied for a while in Jamaica and took a course in reading and writing in Manchester. This means that he dealt, and is still dealing with different people. Accordingly, his language is expected to be influenced more than that of the barber.

As for the second category, it comprises 60 native speakers of Hejazi Urban Dialect (HUD), a variety of Arabic spoken in the urban areas of the Western province of Saudi Arabia, mainly Makkah, Madinah and Jeddah. They were divided into three groups, 20 in each. None of them had lived in an English-speaking country before the time of study. The first group consisted of pupils at the third year of their intermediate school. Their age ranged from 14 to 16 years. They had been studying English for three years, four hours a week. The second group was pupils of the third year at secondary school. They were between 17 and 18 years of age. They had been exposed to English for six years at a frequency of four hours a week. The third group was university undergraduate students (third year level). They studied different subjects. They had been studying English for nine academic years.

\subsection{Data Collection}

Data gathering is based on three factors; firstly, the author once lived with the two Jamaican speakers for two years, which enabled him to observe a great deal of the properties of their speech. Secondly, the researchers had already taken permission from them, and they welcomed the idea of investigating their language by any means. To avoid exaggeration and what is called observation paradox, the researcher chose to record their speech when they were unaware that he did so. This-it is hoped-would guarantee spontaneous (that is natural) speech. Thirdly, in the process, he gave them separately a list of words carrying the fricative in question to read, which is given in Table 1. In addition, examples will be citied in the analysis from the subjects' casual speech when appropriate. It is important to mention that the Broad Jamaican Creole transcriptions in this study are based on Cassidy (1961) and Cassidy and Le Page (1967), and the RP counterparts on Gimson (1980) and Roach (2000). Transcribing and codifying data were done by the researcher himself, then checked by trained transcribers and a phonologist at the University of Bangor, North Wales. Data was coded manually to identify the alveo-palatal

Table 1. Words produced by the barber and the driver and sentences uttered by them in casual speech.

\begin{tabular}{ccccc}
\hline Gloss & Driver & Barber & JC & RP \\
\hline Garage & /gəra:dz/ & /gəra:dz/ & /gəra:dz/ & /gəra:3/ \\
Measure & /midzər/ & /midzər/ & /midzə(r)/ & /mezə/ \\
Treasure & /tridzar/ & /tridzar/ & $/$ tridzar/ & /trezə/ \\
Beige & /be:dz/ & /be:dz/ & /be:dz/,/biedz/ & /beiz/ \\
Mirage & /mira:dz/ & /mira:dz/ & /mira:dz/ & /mira:3/ \\
Television & /tilivizən/ & /tilividzpn/ & /tilividzpn/ & /telivizən/ \\
\hline
\end{tabular}


fricative involved. For reference regarding Jamaican talk of the subjects, Cassidy (1961), Cassidy and Le Page (1967), Bailey (1966), and Holm (2000) were consulted. As for the Arabic speakers, the author referred to Basalamah (1990) and to his intuition as a native speaker of the dialect spoken by the Arab subjects. The Arab learners were given a list of words containing the fricative in question. The words were read out by a native speaker of English in a sound treated room. The learners were asked to read the list twice before they were recorded individually when they were ready. The recording was transcribed by the author and a trained native speaker of English, and then given to a phonetician to verify the transcription.

The following sentences are also produced by the Creole speakers:

Barber: /dıs tıyızu:dz/ This thing is huge.

Cab driver: /dis tıjızju:z/ This thing is huge.

Barber: /i: we:ks in dətredzəri/ He works in the treasury.

\section{Analysis and Discussion}

\subsection{Analysis}

Looking at the phonemic inventory of our Jamaican speakers (Table 2), the first thing that strikes us is the availability of one consonant phoneme that is not in the phonemic inventory of the Broad Jamaican Creole (JC, henceforth), Bailey (1966: p. 14). This phoneme is the voiced palato-alveolar fricative /3/. It is produced in the pronunciation of the word "television", which is rendered as /t1l11vizən/ (see Table 1). The same phoneme, however, is used wrongly in the pronunciation of "huge", which is articulated as /ju:z/ by the same person, the driver (in the pronunciation of "This thing is huge"). In other words, the voiced palato-alveolar fricative / $3 /$ which is always replaced by the voiced alveolar affricate /dy/ in Broad Jamaican Creole is used in the same way by one Jamaican speaker and in a rather unsystematic fashion by the other. Thus, in the pronunciation of "garage", both speakers produce the palato-alveolar affricate /d $3 /$ instead of the RP/3/. On the other hand, the driver substitutes /3/ for /dz/ in "huge", where it should not be used. This behaviour is known as "hypercorrection", or "hyperadaptation". That is, the cab driver seems to have become aware of the fact that $/ 3 /$ is a phonological segment in the English phonemic inventory, as he produces it in "television". However, he does not extend his knowledge to words such as "garage", "measure”, "beige”, etc., where he mispronounces $/ 3 /$ as $/ \mathrm{d} /$ /. Thus, according to Wells (1973) the adaptation made by Jamaicans ranges from zero (no change) to complete (full acquisition of British-like pronunciation). This may mean that the cab driver has moved a step in the direction of the target sound. The reader should be reminded that $/ 3 /$ does not exist in the phonemic inventory of the Broad Jamaican Creole (cf. Bailey, 1966; Holm, 20001). But this substitution could be due to the fact that /dz/ is the sound used in the local dialect. Indeed, according to Allan Thomas (of Bangor, North Wales), it is used in most British dialects. On the other hand, our learners produce words such as "usual", "measure", "garage”, and "beige" with the voiced palate-alveolar affricate /dy/ (i.e. they made the same substitution as the Jamaican speakers) (see Table 3). This is

Table 2. The phonemic inventory of the barber and the driver.

\begin{tabular}{|c|c|c|c|c|c|c|c|c|c|}
\hline & Bilabial & labiodental & Dental & Alveolar & Post Alveolar & Palato Alveolar & Palatal & Velar & Glottal \\
\hline Plosive & p, b & & & $\mathrm{t}, \mathrm{d}$ & & & & k, g & $?$ \\
\hline Affricate & & & & & $\mathrm{tr}, \mathrm{dr}$ & tf, ds & & & \\
\hline Fricative & b & f, v & $\theta$, д & $\mathrm{s}, \mathrm{z}$ & & $\int, 3^{2}$ & & & $\mathrm{~h}$ \\
\hline Nasal & $\mathrm{m}$ & & & $\mathrm{N}$ & & & & $\mathrm{n}$ & \\
\hline Lateral & & & & 1 & & & & & \\
\hline $\begin{array}{c}\text { Frictionless } \\
\text { continuant or } \\
\text { glides }\end{array}$ & $\mathrm{w}$ & & & & $\mathrm{r}$ & & $\mathrm{j}$ & & \\
\hline
\end{tabular}

${ }^{1}$ This sound was lacking in the phonemic inventories of both West African Languages (the substrate languages of JC) and the British dialect of the $17^{\text {th }}$ century (the superstrate language on which JC is based). In fact, the fricative in question was not naturalized as an English phoneme until the end of the $17^{\text {th }}$ century (Cassidy \& Le Page, 1967), and it is lacking in today's JC (c.f., Nyvlte, 2012).

${ }^{2}$ Although the use of this sound is very limited in that it is articulated twice only by one speaker, we would like to assume that it is part of the phonemic inventory of the speakers taken as a group. Hence, the existence of this phoneme in the above inventory will make it different from that of the Broad Jamaican Creole as suggested by Cassidy (1961), Cassidy and Lepage (1967), and Wells (1973, 1982). 
Table 3. Sample of Arab Learners' pronunciation of / $/ 3$.

\begin{tabular}{ccc}
\hline Gloss & Arab Pronunciation & RP \\
\hline Garage & /gara:dz/ & /gæra:3/ \\
Pleasure & /plidzar/ & /plezə/ \\
Treasure & /midzar/ & /trezə/ \\
Measure & /tridzar/ & $/$ mezə/ \\
Leisure & lidzar/ & /lezə/ \\
Beige & /be:dz/ & /beiz/ \\
Usual & /ju:dzwal/ & /ju:zuəl/ \\
\hline
\end{tabular}

not a phonemic error, since it does not result in confusing minimal pairs. And as will be mentioned later, even native speakers of English substitute /d $/$ / for / $/ 3$ in certain environments without causing any confusion (Gimson, 1980). What our learners do not do is produce / $3 /$ instead of /dz/ for the following reasons. On the one hand, / $3 /$ is not part of the Hejazi Arabic phonemic inventory and most Arabic varieties, although it is used as an allophone of /dy/ in some Arabic dialects such as Lebanese and Damascene (Buckwalter \& Mamouri, 2004) and the Arabic varieties spoken in Morocco, Tunisia, and Algeria (Heath, 1987; Frisch 2004; Abu Shaqra, 2007). Based on Jakobson's (1968) hypothesis of "oppositions", it is predictable that our learners will find difficulty in acquiring the fricative in question, as the system of palato-alveolar fricatives is not complete in Hejazi Urban Dialect (HUD). Thus, the gaps in their phonemic inventory indicate that $/ 3 /$ is an alien sound in whose acquisition they will face difficulty. On the other hand, the frequency of occurrence of $/ 3 /$ in English is very low (Denes, 1963). We take the substitution as a clear case of positive transfer. In other words, our learners seem to have identified the fricative $/ 3 /$ with $/ \mathrm{d} /$, a phoneme that is part of their phonological inventory.

\subsection{Discussion}

\subsubsection{Sound Substitution}

Sound substitution is a common practice in foreign/second language learning. Based on a series of studies of second language phonology, Hammarberg (1985) has come to the conclusion that deviation from the target pronunciation usually goes in the direction towards L1 counterparts, and / $\mathrm{d} /$ is the nearest sound to $/ 3 /$ in the Arabic inventory (Basalamah, 1990; Ingham, 1971). But the tendency to substitute /dz/ for / $/ 3 /$ is not confined to our learners only. According to Gimson (1980), in final position, where /3/ is produced in French loan words such as "beige", "prestige", etc., an alternative pronunciation with the voiced affricate is always possible. Moreover, the distribution of $/ 3 /$ is very limited in English. Very few English words begin with this sound and most of them are loan words which have come into the language comparatively recently from French (Gimson, 1980), and not many of these words end with this sound. Once the fricative $/ 3 /$ is absent from the phonemic inventories of both JC and HUD, and once our subjects experience difficulty in realizing it in their speech, one can initially assume that this sound is marked for them, in the sense of Jakobson (1968) and Eckman (1987). It is clear that the process exhibited by the two groups regarding the above sound is the same, namely sound substitution. The same phenomenon of sound substitution is witnessed in child language, as outlined in what follows.

Fricatives in general tend to pose a learning problem for the child. We may draw on Jakobson's (1968) markedness theory to explain this. According to Jakobson, stops are acquired before fricatives and serve as substitute for fricatives. This claim in Atkinson's (1982) sense, is related to the claim that, "in the languages of the world, we can find instances which lack fricatives while containing stops but not instances for which the opposite is true: Therefore, if a language has fricatives then it has stops” (P. 33). In other words, stops are taken to be a prerequisite for the existence of fricatives, and by implication the latter would be more marked than the former. Chiat (2000) reports a number of children struggling to acquire English fricatives. For instance, when Karl, (a child in Chiat's study) targets a fricative, he uses the stop which is produced at the same or nearest place in the mouth. That is, he substitutes [d] for /f/, [b] for /f/, and [d] for /s/ in "dare", "bore", "dum", which were uttered instead of "share", "for", and "some", respectively. In the same study, Eamonn, another child, is found to struggle with /v-f/ distinction. Also, the same phenomenon of substituting stops for fricatives has been reported by Crystal (1987) for normal children, and Miccio and Ingrisano (2000) for a child with a disordered phonological system. According to Smith (2010), all non-sonorant coronals—including / 3 / - surface as [t, d, d] in child 3 and 
the only instance of this sound produced by this child is found in "measure", which is produced with a stop (i.e., [mædæ]). Though the most typical substitute for this fricative in child language is a stop-which squares nicely with Jakobson's (1968) position—a fricative has been reported. Thus, a Quebecois child produces "rouge” as [ju:f] instead of [виз] (MacLeod et al, 2011) and a Dutch produces [fi:af] instead of [зiraf] "giraffe" (Rose \& Inkelas, 2012). ${ }^{3}$

Moreover, despite the differences among the languages to which they are exposed, children from different linguistic backgrounds exhibit significant similarities at the level of babbling. Significantly, the sounds $/ \mathrm{f}, \mathrm{3}, \mathrm{t}$, $\mathrm{d} z /$ are among the infrequently found sounds in their utterances (O'Grady \& Cho, 2001). The fricative / 3 / is reported to be among the most frequently defective phonemes in child language, occurring less than $1 \%$ at the age of 17 and 18 months old (Winitz, 1969). It is not mastered until the age of 7 (Templin, 1957), and in McLeod et al's (2003) survey, it is not fully mastered even after 6 years old. No wonder why /3/ figures as the last consonant in terms of frequency of occurrence of the English phonemes (Denes, 1963). This may be taken as further support to the view that anticipatory complexity and frequency of occurrence are among the factors that affect the acquisition order of consonants (Stokes \& Surrendran, 2005; Winitz, 1969).

\subsubsection{Markedness}

According to O'Grady and Cho (2010: p. 332) "the relative order in which sounds are acquired reflects their distribution in the world's languages. The sounds that are acquired early tend to be found in more languages whereas the sounds that are acquired late tend to be less common across languages”. Furthermore, frequency facts are usually interpreted in terms of markedness, in such that the most frequent sounds are taken to be maximally unmarked and rare sounds are referred to as the most marked ones (Goodluck, 1991). But it seems that certain sounds will remain problematic and hard to acquire regardless of their frequency of occurrence. Thus, although Crystal (1995) assumes that the voiced alveo-palatal fricative in question (i.e. /3/) would be acquired earlier in French as it is more frequent and has a broader distribution in the language, reality has shown the opposite. For instance, Martinet (1974) reports on a survey of 6-year-old French children who managed to master most consonants, but the sibilants /s, z, $\int$, 3 / remained problematic. In a recent study, MacLeod et al's (2011) investigation reveals that the voiced alveopalatal fricative / $3 /$ needs more time to master than most other consonants. Thus, word-initially, it is relatively late in that it is acquired at $24-29$ months. Word-medially, it comes as last sound at 42 to 47 months. Word-finally, the sound is the last to acquire at the age 48 - 53 months. Macleod et al (2011) have come to realize that this fricative together with /v, ь, and w/ are slow to emerge and slow to master, suggesting a higher level of phonetic difficulty (i.e. markedness). In addition, consonant development in paediatric cochlear implant users has revealed an overall pattern of mastery which is consistent with previous studies of typical children (Spencer \& Guo, 2013). For instance, five consonants, including the fricative $/ 3 /$, are still not mastered at 6 years postimplantation.

So far, the subjects (i.e. the Arab learners and Broad Jamaican Creole speakers) do not seem to have acquired the fricative in question, and although the cab driver produces it in two words, he fails to come up with it in most of the words. We take it that this fricative is yet to be established in the phonemic inventories of both HUD and JC, due perhaps to its markedness. A natural behavior in this case is to substitute it with the nearest phoneme in the above inventories, which is the voiced alveo-palatal affricate. This is exactly what happens in child language. In other words, the child is known for substituting a sound (especially if it is marked) with a less marked one at his/her disposal.

But the difficulty of realizing fricatives is not restricted to articulation. Eilers et al. (1977) report that infants appear to have great difficulties in discriminating acoustic attributes that differentiate the class of fricative sounds. In a recent study, Kabak et al. (2007) concluded that their Standard German speakers and Swabian German speakers did not approach native-like perception for English fricatives (which included sibilants). Specifically, they suggested that both interactions with speakers' native inventories and issues of acoustic/perceptual salience probably contributed to the difficulty in the perception of non-native sounds. This finding corroborates that of Tsao et al. (2006). In their study, English-speaking adult score lower than Mandarin-speaking adults on Mandarin alveo-palatal affricate-fricative discrimination. Aslin and Pisoni (1980) argue that this perceptual finding parallels the well documented retardation in the articulatory control of the class of fricatives.

\footnotetext{
${ }^{3}$ Moreover, Shih (2012) reports that Taiwanese-Guoyu bilingual children have substituted the stops [t, th, p] and the affricates [ts, $t$ ] for the voiceless alveopalatal fricative / $/$. Though the sound meant in Shih's investigation is the voiceless counterpart of /z/, this can still be taken as further support to the effect that an affricate is among the substitute candidates of an alveo-palatal fricative.
} 
It seems that the difficulty associated with the acquisition of English fricatives by learners from different linguistic backgrounds (James, 1989) can best be explained in terms of this parallelism. For instance, James points to the fact that dental fricatives, especially, and the contrast between labio-dental, dental and alveolar fricatives and alveolar stops in general, have proven to be a problem area in the acquisition of English phonology for speakers of Hungarian, German and Dutch (c.f. James, 1989, for illustrations). Speakers of Finglish (a variety of English spoken by immigrants of Finnish origin in the United States and Canada) who do not have interdental and palato-alveolar fricatives and affricates treat these English sounds as indicated below:

a) The palato-alveolar affricates $/ \mathfrak{t} /$, /d $/$ / (as in church and jar, respectively become depalatalized to [ts] before a short vowel. Thus garage (gəraz) is realized as [raatsi]; they become a long fricative /ss/ after /n/, e.g., orange is pronounced [orenssi].

b) The palato-alveolar fricatives $/ \int, 3 /$ as in short and azure become /s/, e.g., shower is pronounced [sauveri].

c) The interdental fricatives $[\theta, \delta]$ become $/ t /$, e.g. birthday is pronounced as [potteri].

d) The voiceless fricative /f/ and the glide /w/ become a voiced fricative /v/, e.g. forest becomes [voresti]; wire becomes [vairata] (Randell, 2004).

Further illustration of the struggle in the acquisition of English fricatives is found in the interlanguage phonology of Hong Kong English which manifests the following behaviour with respect to $/ \theta, \partial, 3, v /$. The voiceless interdental $/ \theta$ / is realized as the voiceless labio-dental fricative [f], e.g. thin is producedd as [fin]. The voiced inter-dental fricative /ð/ is produced as the voiced alveolar stop [d], e.g., this becomes [dis]. The voiced alveolar-palatal fricative $/ 3 /$ is articulated as its voiceless counterpart $/ \mathrm{J} /$, e.g. pleasure is produced as [plefə]. And words which are phonologically produced in other varieties with the voiced labio-dental fricative $/ \mathrm{v} /$ are represented in Hong Kong English with either /f/ or /w/ (cf. Hung, 2004).

The voiced alveolar-palatal fricative $/ 3 /$ is acquired late by the child compared to other fricative sounds. According to Winitz (1969), /f/ is mastered at three and /v/ at six, / $/$ / at four and a half and / $/ 3 /$ at seven, and / $/ \mathrm{f} /$ at four and a half and /dz/ at seven. It is clear that the voicing feature separates these cognates by two or more years (cf. Templin, 1957). The above alveo-palatal affricate sounds are also reported to be the most misarticulated sounds by defectively speaking children and adults (Winitz, ibid).

Ladefoged and Maddieson (1996) have rightly pointed to the complicated gymnastics involved in the articulation of fricatives. According to them, "in a fricative a variation of one mellimeter in the position of the target of the crucial part of the vocal tract makes a great deal of difference. There has to be a very precisely shaped channel for a turbulent airstream to be produced" (p. 137). Acoustically speaking, sibilants (including /3/) are known for higher energies in power spectrum and are categorized based on noise duration and other considerations. But a more commonly used measure of the spectral information of sibilants according to Shih (2012) is the "pectral moment analysis". ${ }^{4}$

From the above illustrations one can easily infer that mastery of the class of fricatives will not be an easy task, especially for those whose phonemic inventories lack them. Perhaps the variation in the substitute sounds is a good indication that this class is problematic. But of all the above fricatives, the voiced alveo-palatal $/ 3 /$ seems to be least amenable to acquisition. For instance, Templin's (1957) data has revealed (though not explicitly), that sounds that are not acquired until the age of seven are, nevertheless, uttered by a good proportion of the children at age three. Thus, though the phonemes $/ \delta /, / z /, / 3 /$, and $/ d^{3} /$ are not fully mastered by seventy-five percent of Templin's subjects until the age of seven, all of them do occur in the speech of those children with some frequency at age three; the lowest percentage of correct utterances is $13.7 \%$ for $/ 3 /$, and the highest percentage of correct utterances is $55.2 \%$ for $/ \mathrm{d} 3 /$. This finding is very significant. That is, all our learners and both of the Jamaican speakers' renditions of the voiced alveolar-palatal / $/ 3$ (with few exceptions) were realized as the voiced palato-alveolar affricate /d $/$. One fact one can conclude from this is that / $/ \mathrm{J} /$ is less marked than $/ 3 /$, and therefore it is acquired first and used as a substitute for the more marked /3/. This grants support to Eckman (1977), and Jakobson's (1968) assumption that less marked phenomena are acquired before more marked ones. Thus, it stands to reason to view / $/ 3 /$ as a marked sound which requires time and effort to acquire. This would make us question why this sound is difficult, in the first place. The answer is hoped to be revealed by the history of the sound.

\subsubsection{Historical Change and Decreolization}

Historically speaking, according to Cassidy and Le Page (1967) this sound is alien to English in that it was not ${ }^{4}$ (See Shih (2012) and the references therein for details). 
known in Middle English. In fact, this sound was lacking in the phonological inventories of both West African languages (the substrate languages of JC and British English dialect of the $17^{\text {th }}$ century (the superstate language) as mentioned earlier. In present English, / $/ 3$ derives from a coalescence of the voiced alveolar $/ z /$ with the palatal /j/, and it seems to have merged with French $/ 3 /$ which came to English as a result of recent lexical borrowing from the latter (Gimson, 1980; Bynon, 1977; Lehman, 1962). Specifically, it derives from French /3/ in words adopted after earlier French /dz/ had given / $3 /$, in the pronunciation of such words as, prestige, rouge, garage, beige, etc. (Gimson 1980: p. 190).

According to Bynon (1977), English words, such as restaurant and garage, which have been borrowed recently from French end in a nasalized vowel and a voiced alveolar-palatal fricative, respectively, which are taken to be abnormal features by speakers of English. This abnormality has been eliminated by the language during the course of time. Thus, the two words have completely integrated to the phonological rules of English in that; today they are produced as [restrant] and [gærıd3], respectively. Notice that the new pronunciations end in sounds that are distributionally identical with those of native English words. In fact, we can assume that it was its marked composition that led / $3 /$ to be fully integrated in English by identifying it with the less marked /dz/. Also, the voiced palato-alveolar fricative is not classified among the earlier Creole English phonological system proposed by Alleyne (1980), and according to Holm (2000), "many of the early creoles apparently had only voiceless fricatives"' (p. 154). Thus, we can at least speculate that it was not known in the early creole languages. Moreover, compared to the other members of the class of fricatives, the distribution of $/ 3 /$ is much more limited. Only few English words begin with this fricative and most of them have come into the language comparatively recently from French. Even though, not many of these words end in this fricative (Roach, 2000). In addition to that, lack of minimal pairs that are distinguishable by / $/$ / and / $/ 3 /$ would give the impression that these sounds are allophones in such words as "Asia”, "Persia”, "version”, etc. (Gimson, 1980).

The most striking conclusion from our discussion pertaining to the pronunciation of the voiced alveolar-palatal fricative is that, the voiced alveo-palatal affricate / $\mathrm{d} /$ / is apparently the most favoured candidate to replace the fricative in question. It is used as a substitute by English L2 learners (including our learners), in the speech of English based creoles (including our Jamaican speakers) and, as mentioned earlier according to the sociolinguist Allan Thomas of Bangor, North Wales (personal contact), /dz/ is the sound that is usually used to produce words such as "garage”, "beige”, etc. in most British dialects (see also Gimson, 1980). And once /d子/ has the highest percentage of correct utterances among the other members of the class of fricatives in child language, as mentioned earlier, one would like to assume that, during the acquisition of the class of fricative sounds, the child is expected to choose the affricate / $\mathrm{d} / \mathrm{as}$ a second substitute for $/ 3 /$ after a stop in the early stage of acquisition. This assumption hinges on the following justification. First, /dz/ is probably the least marked alveolar-palatal sound, as the above percentages of mastery suggest. Secondly, it is the sound used in the pronunciation of words containing / $/ 3 /$ in most British dialects. Thirdly, it is the most preferred substitute. Fourthly, the fricative $/ 3 /$ is originally derived from the affricate $/ \mathrm{d} z /$, as mentioned earlier. Thus, it seems that a clear behaviour pattern is shared by the two domains under discussion, namely, creolization, and second language learning (i.e., L2). In other words, the voiced alveo-palatal fricative $/ 3 /$ is treated in the same way by the adult learning L2 and by the speaker of an English-based Creole. Mention has been made of the fact that the child would opt for the same sound substitution in L1 acquisition. This common behaviour is thought to be instigated by the complexity of this sound and perhaps, by its resemblance to the voiced affricate /dz/. Another fact that can be drawn from this work is concerned with the role transfer and markedness can play in acquisition. Thus, having encountered the novel and marked fricative, our subjects have no choice but to lean on their phonemic inventories looking for the nearest substitute for the sound in question, thus simplifying its articulation. It seems that language learning (whether L1, L2 or pidgin/creole) is achieved through above-mentioned strategies (i.e., sound substitution, transfer, etc.). And once we are investigating processes of language learning, it sounds reasonable to shed light on decreolization as one informative source of insights into how language is internalized in the mind of those who are involved in the learning task.

In the situations where the speakers of creole come in contact with the speakers of the superstrate language, i.e. the lexical donor language, there has been a historical tendency for the Creole to shed its most salient features which set it apart from the donor language which is usually European. This process is known as "decreolization". It results in "a continuum of varieties from those farthest from the superstrate (the basilect) to those closest (the acrolect), with mesolectal or intermediate varieties between them” (Holm, 2000: p. 10). The extent to which an individual speaker is decreolized, will, of course, be determined by the amount of the encounter he/ 
she has with acrolectal speakers. That is, an individual's linguistic development is socially determined (Schumann \& Stauble, 1983). For instance, Rickford (1999) reports that Mr. Seymour, a cane-cutter who can speak a basilectal/lower mesolectal variety of Creole, rarely uses this in the interview situations. As a "big-time" contractor, with plenty of occupational and other contacts outside the village where he lives, he generally uses an upper mesolectal/acrolectal variety with his interviewees. Mr. Seymour's younger daughter Katherine, who goes to school, however, speaks what Rickford (ibid) calls an almost flawless acrolet, and amazingly enough, seems incapable of speaking the basilectal and lower mesolectal realizations of Creole.

According to Le Page and Tabouret-Keller (1985), commenting on DGL, a speaker of Belizean English-based Creole who left the Creole environment, she was much on her guard linguistically than she had been earlier when she had been one of the "broader Creole speakers". They add, however, that other Belizeans who do not have the same chance and therefore have to remain as agricultural labourers or as factory workers exhibited less linguistic change. From the above situation Rickford (ibid) concluded that, urged by the awareness of the so called social prestige and stigma associated with the varieties of Belizean speech (hence a psychological motive), those speakers did their utmost to increase their capability in using lects closer to the standard English end of the continuum.

Along the following lines, an attempt will be made to report to what extent our Jamaican informant's pronunciation of $/ 3 /$ has changed, as a result of their immigration to Britain. Their performance will be compared with that of our Arab learners of English, to see to what extent the linguistic processes exhibited in creolization/decreolization parallel those of second/foreign language learning.

In our discussion mention has been made of the fact that the voiced palato-alveolar fricative $/ 3 /$ is lacking in the phonemic inventory of the Broad Jamaican Creole (cf. Bailey, 1966; Alleyne, 1980) and the Hijazi Urban dialect; nonetheless, our Jamaican cab driver managed to produce this sound successfully in "television". Not only that, his awareness of its existence in English made him exaggerate and use it where it should not be used (c.f pronunciation of "huge"). We take it that, the nature of his jobs (as a cab driver and a carpet fitter) necessitates contacts with diverse speakers a lot of whom are speakers of Standard English. These contacts must have contributed towards the modification of his Broad Jamaican Creole, unlike the barber whose work environment does not facilitate any contact with speakers of other English varieties than the Broad Jamaican Creole and other Caribbean creoles.

Our learners in this study still lag behind and stick to the voiced affricate /dz/ as a substitute for/3/. This may be referred to less exposure to the novel sound either through formal instructions or contact with speakers of standard varieties. To coincide with the terms "basilect", "mesolect", and "acreolect", which are used to describe speech varieties, the terms "basilang”, "mesolang” and "acrolang” have been introduced in second/foreign language research, to refer to the corresponding speech varieties along the second language continuum (Schumann \& Stauble, 1983). Thus, we would like to employ the above terms and assume that one of our Jamaican speakers, namely, the cab driver, has shown some progress in his speech and thus has moved along the continuum from a basilect. In other words, although the two Jamaican speakers as well as the Arab learners are engaged in cognitive processes which involve the internalization of knowledge, according to McLaughlin (1987), it is only one subject (namely, the cab driver) who is assumed to have developed his pronunciation with regard to the fricative under study toward a target-language norm. His pronunciation of the sound in "television" and "huge" suggests that he is in the process of restructuring his internal representations to match the target language by access to native speakers (McLaughlin, ibid). The Arab learners and the barber are still at the basilang and the basilect stages, respectively. We expect that initiation and more exposure to the target fricative through formal instruction and contacts with native speakers will enable them to come up with the required pronunciation of this sound.

\section{Conclusion}

This paper has attempted to investigate the validity of the claim that the strategies employed by second/foreign language learners are, more or less, the same as those used by speakers of creole languages. To this end, the speech of two speakers of the well-known Broad Jamaican Creole has been checked against the performance of Saudi learners of English, with respect to the pronunciation of the voiced alveo-palatal fricative /3/. It has been found that the speakers in the two groups produce the voiced affricate /dz/ instead, suggesting perhaps that the above claim is valid. Moreover, the sound substitution made by the speakers has been reported to figure in child language and historical sound change. These findings can help research in language acquisition and learning and also curriculum design which has implications in in-calss learning and teaching. 


\section{References}

Abu Shaqra, F. (2007). Arabic: An Essential Grammar. Routledge: London.

Alleyne, M. C. (1980). Comparative Afro-American: An Historical-Comparative Study of English based Afro-American Dialects of the New World. Ann Arbor: Karoma.

Aslin, R. N., \& Pisoni, D. B. (1980). Some Developmental Processes in Speech Perception. In G. YeniKomshian, J. F. Kavanagh, \& C. A. Ferguson (Eds.), Child Phonology: Perception and Production (pp. 67-96). New York: Academic Press.

Atkinson M. (1982). Explanations in the Study of Child Language Acquisition. Cambridge: Cambridge University Press.

Bailey, B. (1966). Jamaican Creole Syntax. Cambridge: Cambridge University Press.

Baxter, A., Lacchesi, D., \& Guimaraes, M. (1997). Gender Agreement as a "Decreolizing” Feature of an Afro-Brazilian Diatect. Journal of Pidgin and Creole Languages, 12, 1-57. http://dx.doi.org/10.1075/jpcl.12.1.02bax

Basalamah, M. S. (1990). A Study of Certain Aspects of the Suprasegmentals of Arabic and their Influence on the English Pronunciation of Arab Teachers of English. PhD Dissertation, London: University of London.

Bickerton, D., \& Odo, C. (1976). General Phonology and Pidgin Syntax. Vol. 1 of Final Report on National Science Foundation Grant No. Gs-39748.

Bickerton, D. (1995). Creoles and the Bankruptcy of Current Acquisition Theory. In W. Herman (Ed.), Creole Languages and Language Acquisition (pp. 33-43). Berlin: Mouton de Gruyter.

Broselow, E. (1983). Non-obvious Transfer: On Predicting Epenthesis Errors. In S. Gass, \& G. Selinker (Eds.), Language Transfer in Language Learning (pp. 269-280). Rowley: Hewbury House.

Buckwalter, T., \& Mamouri, M. (2004). Guidelines for Transcribing Levantine Arabic: MSA-Based Transcription. https://www.ldc.upenn.edu/sites/www.ldc.upenn.edu/files/nemlar2004-dialectal-arabic-telephone-speech.pdf

Bynon, T. (1977). Historical Linguistics. Cambridge: Cambridge University Press. http://dx.doi.org/10.1017/CBO9781139165709

Cassidy, F. G. (1961). Jamaican Talk. London: Macmillan.

Cassidy, F. G., \& Le Page, R. B. (1967). Dictionary of Jamaican English. London and New York: Cambridge University Press.

Chiat, S. (2000). Understanding Children with Language Problems. Cambridge: Cambridge University Press. http://dx.doi.org/10.1017/cbo9780511791130

Cook, V. (1993). Linguistics and Second Language Acquisition. Basingstoke: Macmillan.

Crystal, D. (1987). The Cambridge Encyclopaedia of Language. Cambridge: Cambridge University Press.

Crystal, D. (1995). The Cambridge Encyclopedia of the English Language. Cambridge: CUP.

Denes, P. B. (1963). Statistics of Spoken English. Journal of the Acoustical Society of America, 35, 892-904. http://dx.doi.org/10.1121/1.1918622

Eckman, F. (1977). Markedness and the Constrastive Analysis Hypothesis. Language Learning, 27, 315-330. http://dx.doi.org/10.1111/j.1467-1770.1977.tb00124.x

Eckman, F. (1987). The Reduction of Word-Final Consonant Clusters in Interlanguage. In A. James, \& J. Leather (Eds.), Sound Patterns in Second Language Acquisition (pp. 143-162). Dordrecht: Foris.

Eilers, R., Wilson, W., \& Moore, J. (1977). Developmental Changes in Speech Discrimination in Infants. Journal of Speech and Hearing Research, 20, 766-780. http://dx.doi.org/10.1044/jshr.2004.766

Frisch, S. (2004). Language Processing and Segmental OCP Effects. In B. Hayes, R. Kirchner, \& D. Steriade (Eds.), Phonetically-Based Phonology (pp. 346-371). Cambridge: CUP. http://dx.doi.org/10.1017/CBO9780511486401.011

Gimson, A. C. (1980). An Introduction to the Pronunciation of English. London: Edward Arnold.

Goodluck, H. (1991). Language Acquisition: A Linguistic Introduction. London: Blackwell.

Hammarberg, B. (1985). Learnability and Learner Strategies in Second Language Syntax and Phonology. In K. Hyltenstam, \& M. Pienemann (Eds.), Modelling and Assessing Second Language Acquisition (pp. 153-175). Clevedon Avon: Multilingual Matters.

Heath, J. (1987). Ablaut and Ambiguity: Phonology of a Morroccan Arabic Dialect. Albany, NY: State University of New York Press.

Holm, J. (2000). An Introduction to Pidgins and Creoles. Cambridge: Cambridge University Press. http://dx.doi.org/10.1017/cbo9781139164153

Hung, T. (2004). Innovation in Inter language Phonology: Evidence from Hong Kong English. 
http://www.waseda.jp/ocw/AsianStudies/9A-77WorldEnglishSpring2005/LectureNotes/03_HKE_TonyH/HKE_unit5.pdf

Ingham, B. (1971). Some Characteristics of Meccan Speech. Bulletin of the School of Oriental and African Studies, 34, 273279. http://dx.doi.org/10.1017/S0041977X00129544

Jakobson, R. (1968). Child Language, Aphasia and Phonological Universals. The Hague: Mouton. http://dx.doi.org/10.1515/9783111353562

James, A. (1989). Linguistic Theory and Second Language Phonological Learning: A Perspective and Some Proposals. Applied Linguistics, 10, 367-381. http://dx.doi.org/10.1093/applin/10.4.367

Kabak, B., \& Maniwa, K. (2007). L2 Perception of English Fricatives in Clear and Conversational Speech: The Role of Phonemic, Phonetic, and Acoustic Factors. www.icphs2007.de

Ladefoged, P., \& Maddieson, I. (1996). The Sounds of the World's Languages. Oxford: Blackwell.

Lefebvre, C., White, L., \& Jourdan, C. (2003). L2 Acquisition and Creole Genesis. Philadelphia, PA: Benjamins.

Lehman, W. (1962). Historical Linguistics: An Introduction. New York: Holt, Rinehart and Winston, Inc.

Le Page, R., \& Tabouret-Keller, A. (1985). Acts of Identity: Creole-Based Approaches to Language and Ethnicity. Cambridge: CUP

Martinet, J. (1974). A propos d'une enquête sur la phonologie d'enfants d’une école maternelle. La Linguistique, 10, 98-103.

McLaughlin, B. (1987). Theories of Second Language Learning. London: Edward Arnold.

MacLeod, A., Sutton, A., Trudeau, N., \& Thordartottir, E. (2011). The Acquisition of Consonants in Quebecois French: A Cross-Sectional Study of Pre-School and Aged Children. International Journal of Speech-Language Pathology, 13, 93109. http://dx.doi.org/10.3109/17549507.2011.487543

McLeod, A., \& Bleile, K. (2003). Neurological and Developmental Foundations of Speech Acquisition. Proceedings of the American Speech-Language-Hearing Association Convention, Chicago, 13-15 November 2003, 1-12.

Miccio, A., \& Ingrisano, D. (2000). The Acquisition of Fricatives and Affricates. American Journal of Speech-Language Pathology, 9, 214-229. http://dx.doi.org/10.1044/1058-0360.0903.214

O’Grady, W., \& Cho, S. W. (2001). Contemporary Linguistics: An Introduction. Bedford: St. Martin’s.

Patrick-Andre, M. (2006). Second Language Acquisition and Creolization: Same (i-) Processes, Different (e-) Results. Journal of Pidgin and Creole Languages, 21, 231-274. http://dx.doi.org/10.1075/jpcl.21.2.01mat

Randell, K. (2004). Finglish. www.genealogia.fi/emi/art/finglish-by-kent-randell

Rickford, J. (1999). African American English: Features, Evolution, Educational Implications. Maiden, MA: Newbury.

Roach, P. (2000). English Phonetics and Phonology. Cambridge: Cambridge University Press.

Rose, Y., \& Inkelas, S. (2012). The Interpretation of Phonological Patterns in First Language Acquisition. In C. J. Ewen, E. Hume, M. van Oosterdorp, \& K. Rice (Eds.), The Blackwell Companion to Phonology (pp. 2414-2438). Malden, MA: Wiley- Blackwell.

Schumann, J., \& Stauble, A. (1983). A Discussion of Second Language Acquisition and Decreolization. In R. Anderson (Ed.), Pidginization and Creolization ad Language Acquisition (260-274). Rowley, MA: Newbury House.

Schumann, J. (1978). The Pidginization Process: A Model for Second Language Acquisition. Rowley, MA: Newbury House.

Shih, Y. (2012). Taiwanese-Guoyu Bilingual Children and Adults' Sibilant Fricative Production Patterns. Ph.D. Dissertation, Columbus, $\mathrm{OH}$ : Ohio State University.

Smith, N. V. (2010). Acquiring Phonology: A Cross-generational Case-study. Cambridge, UK and New York: Cambridge University Press.

Spencer, L., \& Guo, L. (2013). Consonant Development in Pediatric Cochelear Implant User Who Were Implanted before 30 Months of Age. Journal of Deaf Studies and Deaf Education, 18, 93-109. http://dx.doi.org/10.1093/deafed/ens038

Stokes, S., \& Surendran, D. (2005). Articulatory Complexity, Ambient Frequency, and Functional Load as Predictors of Consonant Development in Children. Journal of Speech, Language, and Hearing Research, 48, 577-591. http://dx.doi.org/10.1044/1092-4388(2005/040)

Templin, M. (1957). Certain Language Skills in Children: Their Development and Inter-relationships. Institute of Child Welfare Monograph 26, Minneapolis, MN: University of Minnesota Press.

Tsao, F., Liu, H. M., \& Kuhl, P. (2006). Perception of Native and Non-Native Affricate Fricative Contrasts: Cross-Language Tests on Adults and Infants. The Journal of the Acoustical Society of America, 120, 2285-2294.

http://dx.doi.org/10.1121/1.2338290

Washabaugh, W. (1977). Constraining Variation in Decreolization. Language, 53, 329-352.

http://dx.doi.org/10.1353/lan.1977.0013 
Wells, J. C. (1973). Jamaican Pronunciation in London. Oxford: Basil Blackwell.

Wells, J. C. (1982). Accents of English 3: Beyond the British Isles. Cambridge: Cambridge University Press. http://dx.doi.org/10.1017/cbo9780511611766

Winitz, H. (1969). Artilculatory Acquisition and Behaviour. New York: Appleton-Century-Crofts. 